Revue Française de Civilisation Britannique

\title{
Interview with David Hendy : Writing an Official History of the BBC in 2020
}

Entretien avec David Hendy : Écrire une histoire officielle de la BBC en 2020

John Mullen and David Hendy

\section{(2) OpenEdition}

Journals

Electronic version

URL: https://journals.openedition.org/rfcb/7628

DOI: $10.4000 / \mathrm{rfcb} .7628$

ISSN: $2429-4373$

Publisher

CRECIB - Centre de recherche et d'études en civilisation britannique

Electronic reference

John Mullen and David Hendy, "Interview with David Hendy: Writing an Official History of the BBC in

2020 ", Revue Française de Civilisation Britannique [Online], XXVI-1 | 2021, Online since 02 December

2020, connection on 05 January 2022. URL: http://journals.openedition.org/rfcb/7628 ; DOI: https:// doi.org/10.4000/rfcb.7628

This text was automatically generated on 5 January 2022.

Revue française de civilisation britannique est mis à disposition selon les termes de la licence Creative Commons Attribution - Pas d'Utilisation Commerciale - Pas de Modification 4.0 International. 


\section{Interview with David Hendy : Writing an Official History of the $\mathrm{BBC}$ in 2020}

Entretien avec David Hendy : Écrire une histoire officielle de la BBC en 2020

John Mullen and David Hendy

1 David Hendy is Professor of Media and Cultural History at the University of Sussex. He is the author of Noise: a Human History of Sound and Listening, which was also a BBC Radio 4 documentary series.

2 He is currently working on a new, authorized history of the $B B C$, which will be published for the BBC's Centenary in 2022. He is also the Principal Investigator on a five-year project, Connected Histories of the $B B C$, which involves bringing the $B B C$ 's own oral history archive into the public realm using innovative digital humanities techniques and ideas. The project is based in the Sussex Humanities Lab, and has the BBC, the Science Museum, Mass Observation, and the British Entertainment History Project as partners.

3 We are very grateful to Professor Hendy for taking the time to guide us "behind the scenes" in the production of BBC history.

JM : THANK YOU VERY MUCH FOR AgREEINg TO BE INTERVIEWED. COULD YOU PERHAPS BEgIN BY DESCRIBINg THE HISTORY OF THE BBC WHICH YOU ARE IN THE PROCESS OF COORDINATING? WHAT ARE ITS PRIORITIES AND HOW DID YOU COME TO BE INVOLVED?

DH: The origins of this project are rather convoluted, since for the past half-decade I have been wearing two hats - and sometimes both at the same time.

Five years ago, I was commissioned to write a single-volume history of the $\mathrm{BBC}$, to be published in time for the Corporation's Centenary in 2022. There are, of course, already the five volumes of official history written by Asa Briggs and, more recently a sixth volume in that series written by Jean Seaton. They are wonderful books, and have been the irreplaceable starting-point for anyone who is conducting serious research into the BBC's history. My commission was not designed to compete with 
them on the same terms; it was to create a single volume history of the $\mathrm{BBC}$, scholarly in approach but accessible to the general reader in style. It is "authorised". This does not mean it provides a hagiography of the $\mathrm{BBC}$ : no-one at the $\mathrm{BBC}$ tells me what to write; they do, however, co-operate in giving me access to archival material that might not otherwise be available to researchers.

At about the same time as I received the commission to write this book, I was approached by Robert Seatter, the BBC's Head of History. Robert's role is nothing to do with making history programmes on TV or radio. It's about supporting public understanding of the BBC's own rich past, and especially its role in society. I was at an event at the British Library, and he was there, too. The gathering was linked to a radio series I had recently written and presented for BBC Radio 4 called Noise: a Human History. It was a long - 30-episode - series which took the listener from prehistory to the present by placing sound and listening centre-stage: how important was the sound of a place or an event - a war, a battle, a ceremony - in the past? What do we learn about the history of the world if we think not of kings and queens and political events but what it sounded like?

Noise: a Human History had been a massive undertaking: working with archivists at the British Library and elsewhere, recording in something like 60 different locations - on 4 continents - over a period of about 6 months. The series had been described by one newspaper critic as "like A History of the World in 100 Objects $^{1}$ - but in sound", and perhaps it was this that got Robert thinking about whether I might be the right person to help him out with something that had been preying on his mind for some time. During a tea-break, he explained it to me. Since 1972, the BBC had been recording interviews with members of staff when they retired or left - programmemakers, senior managers, engineers, presenters, journalists and so on. There were now well over 600 of these "oral history" interviews - some recorded in only in sound and on cassettes, others on film or video; most - though not all - had been transcribed. The entire collection was analogue: laying around in ageing formats, scattered across different parts of the BBC, and largely inaccessible. It was this inaccessibility which frustrated Robert most. There promised to be some extraordinary riches in these interviews - personal ringside accounts of key moments in broadcasting history from figures who had important roles behind-thescenes. The BBC had an enormous and fantastic collection of written archives that were already open to researchers: might it be possible to bring this collection of oral history interviews into the open, too?

The possibility was intriguing, and not just because the history of the $\mathrm{BBC}$ is my main subject of expertise, and so getting my hands on the recordings would be fascinating to me personally. It seemed to me that there was something more that could be done if the project to open up the BBC's oral history collection was based at my own institution, the University of Sussex. First, we had amongst us a critical mass of experts in the history of broadcasting: Dr Alban Webb, who has written an official history of the BBC World Service, Professor Kate Lacey, a historian of radio, and myself. Second, Sussex was home to the Centre for Life History and Life Writing Research, run by Professor Margaretta Jolly - and therefore had a highly-regarded track record in pioneering oral history techniques. It was also home to the wonderful Mass Observation Archive, a "record of everyday life" in Britain in the $20^{\text {th }}$ century made up of thousands of diaries. Third, in our History Department, we had one of the 
leading experts in "digital history", Professor Tim Hitchcock, who had been involved in creating the massive, and massively successful, old Bailey Online - a digital resource encompassing millions of English court records. Fourth, the University was in the process of launching the Sussex Humanities Lab, which provided a research base for all sorts of interesting and experimental work in the fast-expanding field of "digital humanities". And finally, there just seemed something rather neat and poetic about a project like this coming to the very University which Asa Briggs had run back in the 1960s.

To cut a long story short, we pulled all these people and resources together, teamedup with the BBC, Mass Observation, the Science Museum, and a trades-union archive called the British Entertainment History Project, then put in a bid for some money. In 2018 we were awarded just over three-quarters of a million pounds by the Arts and Humanities Research Council, to do something exciting with the BBC's oral history collection.

This is where 100 Voices that Made the BBC comes in - as I shall explain in a moment.

Before that, though, I should add that 100 Voices is only the most visible part of what we are attempting to do in this project. Behind-the-scenes, we are busy trying to create a fully-digitised, fully-searchable, online catalogue of all 600 or so interviews in the BBC's oral history collection. It's a formidable task, not least because the 'raw materials' need not just digitising but so much 'cleaning-up' to make them useful. For instance, we've discovered that we need to get completely new transcripts for each interview by running the recordings through voice-to-text software, so that we have transcripts which accurately match the recordings and so that the recordings themselves can then be searched online. Even this is not straightforward: since noone knows yet whether any sensitive BBC material - or anything defamatory - is in them, we need to ensure this process is conducted in a highly secure way; we've also had to 'train' the software to recognise specialist BBC terms that crop-up in the speech and give us a firm basis for adding lots of new metadata. But in any case, by the end of 2021, we hope to be launching a really wonderful resource which will allow anyone, anywhere in the world, to search the entire collection, listen to and view the recordings, even - and this is the fun bit - do all sorts of playing around with the entire data-set, spotting trends in language use over time, and so on.

This brings me back to 100 Voices that Made the $B B C$. We were aware right from the start that the complex behind-the-scenes work on creating our vast digital catalogue was going to take us years. So we wanted to find a way of sharing some highlights from the collection along the way, as we came across them in our work. And we wanted to make these highlights as accessible as possible - not just to academic researchers but to members of the public: the programmes made by the $\mathrm{BBC}$ over the years have, after all, provided the soundtrack to millions of lives, and the stories behind them are therefore of great interest to lots of people.

The basic idea was to create a new set of web-pages every year, featuring roughly 15 or so oral history recordings each time - and, by the end of 2021, to have featured a grand total of roughly 100 of the most interesting individuals. Hence 100 Voices. The aim was not just to make the recordings widely available by having them hosted by the BBC but - crucially - to provide some sort of academic context which helped explain their significance. My colleague, Alban Webb, and I would "write around" the 
interviews in a way that was informed by our own expertise but delivered in a "blog" style.

\section{JM: ARE THERE ANY DRAWBACKS ASSOCIATED WITH THE FORMAT? WHAT DO YOU IMAgINE WILL BE THE BIggEST CHALLENgES?}

DH: Providing this "academic context" has been our first challenge. The oral history interviews themselves are fascinating. But often they are also what I would call "insider-ish". In other words, they give a very detailed account of, say, a particular an event in BBC history - its role in broadcasting to Europe in World War Two, the origins of TV drama in the 1950s, the Suez Crisis, and so on - but often these oral accounts assume too much knowledge of how the BBC works: names of people, departments, places - these are often mentioned without explanation. The interviewer is usually a former colleague, perhaps a friend. And when two such people encounter each other, there is the advantage of us seeing people being at ease with each other, but also the disadvantage of an interview becoming a chat where each participant knows rather too easily what the other is talking about. These are also, of course, "partial" accounts by people who want to burnish their own reputation and whose memories are sometimes fading a little: this is one of the perennial dangers in any kind of oral history. It means that when Alban and I write the texts which accompany the interview extracts, we always need to put them into a broader context - explaining names, offering a bit of background history, pointing out accounts that conflict with each other, and offering some judgement as to who is giving the more accurate version.

A second challenge has been facing-up to the "absences" in the BBC's oral history collection. Take women, for example. Historically, the BBC has been quite a good employer when it comes to women: even in the 1920s, there were women appointed to quite senior roles - people like Hilda Matheson, who became Head of Talks programmes and Mary Somerville, who ran programmes for schools. But you wouldn't necessarily know this from the BBC's Oral History Collection. There are women included - and their accounts are fascinating. But these represent a disproportionately small part of the overall collection. This mean that women's voices are heard less than they should be, and therefore that accounts of, say, sexist attitudes in the workplace have also not been sufficiently captured in the historical record. Moreover, those areas of $\mathrm{BBC}$ activity where women have traditionally been accorded significant roles - children's broadcasting, for instance - tend to get much less attention. The problem is even worse when it comes to ethnic minorities. As far as I can tell so far, there is not a single person of colour in the collection - at least up until 2001, which is the "cut-off" year for us. This does not just mean that white faces and voices dominate. It also means that really important subjects - how the BBC responded to immigration in the 1940s, 50s and 60s, whether or not it did enough to report on racial prejudice or to promote its own ethnic minority staff, or to reflect minority cultures in its output - are simply not even talked about in these interviews: either to the people selected or the people interviewing them, they did not seem important enough as topics.

What can we do about all this? To some extent, we don't want to hide these absences. They tell us something about the BBC's priorities in the past - its failures, its weakness, its blind-spots. So we have to be very open about showing, and acknowledging the biases in the collection. Yet we don't want to simply accept that 
because no-one talks directly about, say, racial prejudice, we therefore cannot say anything about it in 100 Voices. So we try to do two things. First, we weave into 100 Voices a lot of other material that fills some of the gaps. Chiefly, this consists of clips from some of the 16 million or so programmes the BBC has broadcast over the years. But it also includes some fascinating documents from the BBC's Written Archives, personal accounts from "ordinary" listeners and viewers held in the Mass Observation Archives, and even some entirely new recordings that we have filmed for ourselves with former members of the BBC staff who for one reason or another were not included in the BBC's own collection. The second thing we do is this: armed with this extra contextual material, we can start to feature interviews in the oral history collection which, although they might not directly address the topic, provide some sort of relevant context for it.

The kind of thing we're aiming to achieve is probably best seen in "People, Nation, Empire", the edition of 100 Voices that deals with immigration, race, the legacy of Empire and British identity. As I explained, there was little or nothing being said about these topics in the oral history interviews. Yet, if we look at the BBC's programme archive, we see that there were lots of programmes - dramas, documentaries, and so on - that addressed issues of race and immigration in the 1950s and 1960s; the BBC's programme archive also includes the very first programmes made specially for Asian and West Indian immigrants in the 1960s. Meanwhile, the written archives allow us to trace the history of internal discussions about these programmes: why they were made, what went right, what went wrong, how they were received. In the end, "People, Nation, Empire" included 24 really important documents from the written archives, 45 extracts from television and radio programmes - some of which have never been seen since their first broadcast many decades ago, and 8 extracts from Mass Observation diaries. Once these were pulled together, we could go back to our main source, the BBC's oral history collection, and draw on 28 of the interviews, featuring people talking about other but perhaps "related" subjects: the need to reflect "real life" away from the capital, the need to take account of foreign perspectives, the role of emigres in the BBC's Overseas and European Services in wartime, the need to move beyond a monoculturally Christian approach to religious broadcasting, and so on.

"People, Nation, Empire" has perhaps been the trickiest, most complicated edition of 100 Voices we have created so far. But we've tried to give a flavour of the same approach to all our editions. We try where we can to place the oral history interviews at the centre of each edition, but we try every time not to be constrained by them. In "The BBC and World War Two", ${ }^{3}$ for example, it was important that we took the opportunity to challenge the idea of Britain "standing alone", even during the Blitz. In sections on "The Secret War", "Allies", and "VE Day", we tried to point out the significant role played by foreign refugees in the BBC's wartime broadcasting operations, and draw attention to programmes that took a more internationalist approach. I hope very much that while people enjoy some of the "nostalgia" contained in this particular edition of 100 Voices, they are encouraged to start dismantling a "Little Britain" approach to the war.

JM: IS IT NOT A LITTLE INTIMIDATINg TO BE FOLLOWINg IN THE FOOTSTEPS OF A CELEBRATED HISTORIAN LIKE ASA BRIggS? BRIggS WAS LEFT A TREMENDOUS AMOUNT OF FREEDOM IN WHAT HE WROTE, AND HE OFTEN INSISTED THAT HIS WAS NOT AN OFFICIAL 


\section{HISTORY. Yet ONE COULD ARgUe he WAS CHOSEN bECAUSE He WAS PART OF A RATHER CLOSED AND QUITE ELITIST CIRCLE. ...}

DH: There is, of course, nothing we can do which can possibly compete with Asa Brigg's' monumental work on the history of the BBC. He wrote thousands of pages based on years and years of detailed research. His is undoubtedly the "definitive" account, and will remain so for years to come. But in both the 100 Voices project and my writing of a new history for the centenary, I do want to reveal some differences of emphasis. It's obvious, for instance, that Asa Briggs takes quite a "top-down" approach to the story: he's especially interested in relations with Government, with matters of grand policy, strategy, committees of enquiry, the development of the BBC as an important institution. All of this is important. But I suppose that since I worked for the $\mathrm{BBC}$ as a programme-maker for seven years, I am slightly more attracted to the history of programmes and what people at home make of them. I also feel, perhaps as a result of this experience, that grand policy statements tend simply to reflect existing practice rather than establishing them - that the day-to-day debates and discussions and ad hoc decisions made in the studios and production offices, in what we might call the "middle and lower ranks" was what, collectively and cumulatively, made the $\mathrm{BBC}$ what it was.

So while Asa Briggs certainly drew on the BBC's oral history collection, he tended to focus mostly on the senior figures. I'm attracted to those in the collection who offer a "factory floor" perspective. Just to give one example - the accounts in the collection of preparations for D-Day in 1944, in which it was the BBC's role to announce the June invasion to the world and have men and women in place to report every stage of the military action over the next few months. There are brilliant and fascinating accounts from lots of the senior BBC figures involved, who knew all about the secret invasion plans, who made the announcements on air, and who reported from the fighting on the ground. But the interview that fascinated me most was with Mary Lewis, a duplicating clerk who had to print out all the scripts announcing the invasion. She provides a fascinating "bottom-up" view of working at the BBC throughout the war: the night shifts, being on fire-watch, what she wore to work, how those above her behaved, and, when it came to D-Day, the crucial role that the BBC's duplicating service played in getting programmes on the air. Her account allows us to understand the full range of effort that was involved in the BBC's wartime successes.

To some extent, I hope that by featuring her account, and those like it, we get a more of a "People's" history of the BBC emerging. Perhaps I'm attracted to this idea anyway, because of my background, which is undoubtedly a little less grand and less well-connected than Asa Briggs' and many of those who ran the BBC. I went to a state school, I don't mix with the Great and Good, I am, in truth suspicious of hierarchies, titles, those who feel they are somehow born to rule. One thing that people who read my book may or may not notice is that I avoid all reference to "Lord" or "Lady" or 'Sir'. John Reith, the founding father of the BBC, was knighted and then ennobled. But I shall determinedly only refer to him as simple John Reith.

One other point of departure comes with recent developments in history as an academic discipline. My 2013 BBC radio series Noise: a Human History was one attempt by me to engage with "sensory" history. There are some marvellous historians working on subjects such as sound, smell, and touch. And what they bring, I think, is 
an attention to what it actually felt like to be somewhere at a particular time. There are also some marvellous historians opening up the new field of "emotions" history working on subjects such as happiness, fear, anxiety, love, homesickness, and so on. I find this fascinating and inspiring. And it has encouraged me to think more deeply about what it felt like to work in the BBC, or rather in a particular building or studio, and what kind of atmosphere or mood prevailed in, say, a particular production department. In this respect, I start to look for very different things from the BBC's oral history interview collection. I am looking for emotions as much as facts: the things that people seem particularly angry about or passionate about or frightened of. These provide a sort of "map" of hotspots' - themes of events which aroused the greatest passions.

One example of this is an event during World War Two which Asa Briggs mentions but only really in passing: the time in 1940 when Broadcasting House in central London, the headquarters of the entire BBC operation, was bombed by the Luftwaffe. I was struck by just how many interviewees referred to the event. This seemed to me to tell us something - that it mattered to 'ordinary' members of the BBC staff a great deal. My sense - it's an instinct more than anything I can prove definitively - is that the bombing was a moment which brought home to those at the $\mathrm{BBC}$ that they too were on the front line, that they too were under attack, and that what they did was, in the end, proper "war work" which put their own lives on the line. In the end, I think it encouraged a greater degree of camaraderie and connection with the plight of the civilian population outside.

\section{JM: WHO DO YOU HAVE TO ANSWER TO, IF ANYONE?}

DH: One of the great pleasures of this whole research project is that I don't really have to answer to anyone in terms of what I say or how I say it. The 100 Voices websites are hosted by the BBC, which means that they have to conform to BBC standards in terms of language, taste, accuracy, etc. But that doesn't really require us to do anything we wouldn't do for ourselves in terms of being careful about accuracy or causing offence. Otherwise, no-one tells Alban or I what we can or cannot say. Indeed, some of what we say is uncomfortable for the BBC. In various parts of 100 Voices we tell a story of unequal pay for women, of racial prejudice inside the BBC, and so on. When it comes to the book I am writing, there will be further revelations. But in every instance so far, I have been struck by the BBC's commitment to transparency. It seems to understand, in general, that as a public institution, it needs to own up to past mistakes as well as past successes - and this owning up is part of what makes it a great institution.

\section{JM: WHAT WOULD YOU SAY WERE THE MAIN WATERSHED MOMENTS IN THE HISTORY OF THE BBC IN THE 20TH CENTURY.}

DH: To some extent, the watershed moments in the BBC's story remain fundamentally the same. In the 1920s and 1930s it is the story of a group of dedicated individuals trying to "invent" broadcasting from scratch, a period of experimentation and freedom turning slowly into something more institutionalised and perhaps more conservative, as techniques become routine and public interest increases. The Second World War represented a real turning point, in demonstrating how the BBC was an important part of the war effort - providing reliable information but also moraleboosting escapism - but only if it could find a "popular touch" that ensured people listened. In the late-1940s and 1950s, the BBC's deep interest in elevating the culture 
and knowledge of the citizen seemed to match the "New Jerusalem" ambitions of a socially-reformist Labour Government, but also had to contend with deeply conservative trends in society, in terms of attitudes to women, family-life, language, and literature. There is also the arrival of commercial competition for the first time, with the launch of ITV in 1955. In the 1960s and 1970s, there is a generational shift in attitudes to sex and permissiveness that threw the BBC into the thick of a 'culture war' between reactionaries and progressives - both inside and outside the organisation. In the 1980s and 1990s, the BBC is faced with intense competition from an expanding market in radio and TV, encouraged by Margaret Thatcher and a Conservative Government consistently hostile to the BBC. By the end of the century, the $\mathrm{BBC}$ is having to grapple with rapid technological change - digitalisation and, above all, the Internet - which demands that it works out a new public role if it is to avoid becoming simply one media institution among many.

Throughout this period there are extraordinary flashpoints: the 1926 General Strike and the 1956 Suez Crisis, when Governments threatened to take over the BBC in retaliation for its perceived lack of loyalty; moments during the Falklands and Gulf Wars when its reporting of military atrocities seemed, again, to be disloyal to "our boys"; crises of judgement when it failed to do enough quickly enough about the paedophile celebrity-DJ, Jimmy Savile. And so on. One of the stories is that the BBC is often "the" story. It has been and remains one of the great institutions of British society, like Parliament, the Church, or the Royal Family - though perhaps more important than any of these because its activities span an enormous range, from popular music right through to international security.

\section{JM: HAVE HISTORIANS' VIEWS OF THE BROADCASTINg gIANT THAT WAS JOHN REITH CHANGED VERY MUCH IN RECENT DECADES, AND IF SO, HOW?}

The figure of John Reith looms large - and not just in the 1920s and 1930s, when he founded and ran the BBC. We still talk about "Reithianism". And doing so is proof that something of his spirit still exists in the BBC today. He was a complex man, and Reithianism is a complex idea. But the essence of both was something more than a dour, Presbyterian bossiness. In oral history interview after oral history interview, people say that he was capable of being opinionated, but also remarkably kind and remarkably fair to those who stood up to him. People showed remarkable devotion to him because, frankly, they shared his hopes. And his hopes for the BBC were that it would improve society and help people grow into their better selves. Radio - and later, television - were just the vehicles, the technical means, for achieving this: broadcasting was not and never should be an end in itself.

The core idea in Reithianism was the reverse of the commercial principle that demand creates supply. Reithianism believes the reverse - that what is supplied determines what is demanded: if people are given the chance to experience good things- good music, good ideas, good information, things that they did not know existed or which seemed intimidatingly unfamiliar at first - they would start to demand them. For how can people demand something they do not yet know about or does not yet exist? Once they are introduced to the unfamiliar - brought to them on a tide of the familiar - they will grow, change. Culture, knowledge, intelligence: these are not fixed, they are dynamic. Of course, Reith's view of what constituted "good" culture was narrow. And perhaps the biggest single challenge facing the $\mathrm{BBC}$ over the years has been to widen the definition of what counts as "good". But the essential 
notion, that broadcasting is for everyone - and that, provided it reaches everyone, it might make for a better world on some way, remains, I think, in the DNA of the BBC today.

A final point, I should add. I can't much of the credit for this view of the BBC, or for our evolving understanding of its history. It is such a complex organisation that has created so much radio and television and public debate over the years, that perhaps no single person can "explain" it in one go. Understanding it, getting to know not just what it has done but how it ticks, and what motivates the people who work for it: this is a collective endeavour involving hundreds of scholars around the world.

\section{JM: FINALLY, APART FROM ASA BRIggS, WHICH HISTORIANS OF BROADCASTING WOULD YOU PARTICULARLY RECOMMEND TO OUR READERS?}

Let me just identify a few key works that make a great starting point, aside from Asa Briggs' five volumes, of course:

Alban Webb, for his book London Calling: Britain, the BBC World Service and the Cold War.

Paddy Scannell and David Cardiff, for their book A Social History of British Broadcasting, Vol. 1, 1922-1939.

Jean Seaton, for her book Pinkoes and Traitors: The BBC and the nation 1974-1987, and for her book with James Curran, Power Without Responsibility.

Sian Nicholas, for her book on the BBC in World War Two, The Echo of War.

And for a more critical account:

Tom Mills, The BBC: Myth of a Public Service.

Finally, watch out for forthcoming books from Jamie Medhurst, on the history of BBC television, and from James Procter on the BBC's role in West Indian and West African literature.

There are currently seven separately themes editions of the '100 Voices that Made the $\mathrm{BBC}$ ' series of websites, which can all be accessed here: https://www.bbc.com/ historyofthebbc/100-voices

Two more will be published in 2021. One will be on 'The BBC and Entertainment', the other on 'The BBC and Inventing the Future'.

\section{NOTES}

1. See online here : https://www.bbc.co.uk/programmes/boonrtd2

2. Online here https://www.bbc.com/historyofthebbc/100-voices/people-nation-empire

3. https://www.bbc.com/historyofthebbc/100-voices/ww2 


\section{AUTHORS}

\section{DAVID HENDY}

David Hendy is Professor of Media and Cultural History at the University of Sussex. He is the author of Noise: a Human History of Sound and Listening, which was also a BBC Radio 4 documentary series.

He is currently working on a new, authorized history of the $B B C$, which will be published for the $B B C$ 's Centenary in 2022. He is also the Principal Investigator on a five-year project, Connected Histories of the $B B C$, which involves bringing the $B B C$ 's own oral history archive into the public realm using innovative digital humanities techniques and ideas. The project is based in the Sussex Humanities Lab, and has the BBC, the Science Museum, Mass Observation, and the British Entertainment History Project as partners. 